\title{
Perbedaan Kadar Interferon Gamma dan Interleukin-10 pada Orang Dewasa Terinfeksi Ascaris Lumbricoides dengan Tidak Terinfeksi yang Diinduksi Vaksin Bacille Calmette-Guerin
}

\author{
Weni Mulyani ${ }^{1}$, Nuzulia Irawati ${ }^{2}$, Netti Suharti ${ }^{3}$
}

\begin{abstract}
Abstrak
Kecacingan merupakan penyakit yang masih banyak di negara berkembang. Infeksi cacing dapat menimbulkan penurunan respon terhadap antigen yang terjadi akibat modified Th2 response. Vaksin BCG merupakan antigen yang dikenal sebagai penginduksi respon sel Th1. Tujuan penelitian ini adalah untuk mengetahui perbedaan kadar IFN-Y dan IL-10 pada orang dewasa terinfeksi Ascaris lumbricoides dengan tidak terinfeksi yang diinduksi vaksi BCG. Penelitian dilakukan di Kelurahan Muara Fajar Kecamatan Rumbai Pesisir Pekanbaru dengan menggunakan rancangan cross sectinal study. Populasi penelitian ini adalah orang dewasa kelurahan Muara Fajar Kecamatan Rumbai Pesisir Pekanbaru yang terinfeksi dan tidak terinfeksi Ascaris lumbricoides. Status kecacingan didapatkan dari pemeriksaan feses dengan metode kato-katz. Kadar IFN-y dan IL-10 didapatkan dengan pemeriksaan laboratorium dengan metode ELISA. Pengolahan dan analisa data menggunakan uji t. Hasil penelitian didapatkan rerata kadar IFN$\mathrm{Y}$ adalah $16,55 \pm 14,13 \mathrm{pg} / \mathrm{mg}$ dan kadar IL-10 36,13 $\pm 8,83 \mathrm{pg} / \mathrm{ml}$. Pada orang dewasa yang tidak terinfeksi Ascaris

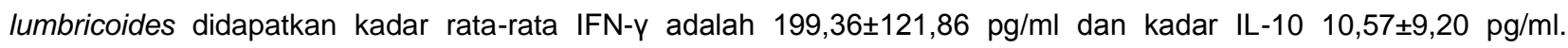
Terdapat perbedaan bermakna kadar IFN- $\gamma$ dan IL-10 antara orang dewasa yang terinfeksi Ascaris lumbricoides dengan tidak terinfeksi $(p<0,05)$. Kesimpulan hasil penelitian ini ialah infeksi Ascaris lumbricoides dapat menekan produksi IFN-y terhadap pemberian vaksin BCG.
\end{abstract}

Kata kunci: ascaris lumbricoides, vaksin BCG, interferon gamma (IFN-ץ), interleukin 10 (IL-10)

\begin{abstract}
Worm infestation still happened in the develop country. Worm infection can also make low respond on antigen that is caused by modified Th2 response. BCG vaccine is antigen as known as induction Th1 cell respond. The objective of this study was to know the differences IFN-y and IL-10 an adult who infected Ascaris lumbricoides to uninfected who inducted by BCG vaccine. The research was conducted in Muara Fajar district Rumbai Pesisir Pekanbaru by Cross Sectinal Study. The research population were adults in Muara Fajar district Rumbai Pesisir Pekanbaru who infected and uninfected Ascaris lumbricoides. Worm infection was getting checked in fesses by katokatz method. IFN-y and IL-10 were getting laboratory checked by ELISA method. The data was analyzed by $t$-tes. The mean IFN-y of the adult who infected Ascaris lumbricoides were $16.55 \pm 14.13 \mathrm{pg} / \mathrm{mg}$ and IL-10 $36.13 \pm 8.83 \mathrm{pg} / \mathrm{ml}$ and the adult who uninfected Ascaris lumbricoides were $199,36 \pm 121,86 \mathrm{pg} / \mathrm{ml}$ and $\mathrm{IL}-1010.57 \pm 9.20 \mathrm{pg} / \mathrm{ml}$. There was significant difference of IFN-y and IL-10 between adult who infected Ascaris lumbricoides with uninfected $(p<0,05)$. It can be concluded that Ascaris lumbricoides infection can pressure IFN-y production on given BCG vaccine.
\end{abstract}

Keywords: ascaris lumbricoides, BCG vaccine, interferon gamma (IFN-Y), Interleukin 10 (IL-10)

Affiliasi penulis: Program Studi S2 Biomedik FK UNAND (Fakultas Kedokteran Universitas Andalas Padang), 2. Bagian Parasitologi FK UNAND, 3. Bagian Mikrobiologi FK UNAND

Korespondensi: Weni Mulyani, E-mail : weniaja198@yahoo.co.id, Telp: 085263607052

\section{PENDAHULUAN}

Salah satu penyakit kecacingan adalah penyakit cacing usus yang penularannya dengan perantaraan tanah atau Soil Transmited Helminths 
(STH). Lebih dari 2 milyar orang di seluruh dunia terinfeksi oleh satu atau beberapa spesies dari STH. ${ }^{1}$

Di Indonesia, menurut Departemen Kesehatan (Depkes) 2011 prevalensi kecacingan masih relatif tinggi yaitu sebesar $32,6 \%$, yang didominasi oleh Ascaris lumbricoides. ${ }^{2}$ Data Dinas Kesehatan Kota Pekanbaru tahun 2012 menunjukkan kasus kecacingan dari 20 puskesmas tercatat 2285 kasus, dimana 225 kasus terdapat di puskesmas Rumbai Pesisir.

Beberapa penelitian menunjukkan bahwa anak usia sekolah dasar memiliki persentase infeksi yang paling tinggi, hal ini disebabkan karena perkembangan imunitas selulernya belum berkembang sempurna seperti pada orang dewasa oleh karena itu anak-anak lebih mudah terinfeksi jika dibandingkan dengan orang dewasa. Pada kenyataannya cacing dapat juga menyerang orang dewasa yang sistem imunitasnya sudah sempurna, hal ini mungkin dipengaruhi oleh lingkungan sekitar dan jenis pekerjaan. Penyakit ini biasanya mudah mengenai orang-orang yang bekerja di daerah kumuh dan terpapar langsung dengan tanah sehingga memberi kesempatan untuk terkena infeksi ascariasis. ${ }^{3}$

Pada infeksi cacing kronis disamping merangsang respon sel $\mathrm{T}$ helper 2 (Th2) yang kuat juga mendorong penekanan populasi sel $\mathrm{T}$ oleh $\mathrm{T}$ regulator ( $T$ reg) yang dikenal dengan modified Th2 response. Beberapa penelitian telah membuktikan pada individu yang terinfeksi antigen spesifik cacing menunjukkan respon T-helper 1 (Th1) yang rendah. T reg memproduksi sitokin inhibitor yaitu Interleukin-10 (IL-10) yang menyebabkan hyporesponsive yang tidak hanya diarahkan untuk antigen cacing tetapi juga kepada antigen asing lain, seperti antigen vaksin atau patogen lainnya. ${ }^{4-7}$

Infeksi cacing yang kronis dapat mengurangi respon imun tubuh terhadap vaksin Bacille CalmetteGuerin (BCG) sehingga mudah terinfeksi penyakit tuberculosis (TB). ${ }^{4}$

TB menginfeksi sepertiga populasi dunia dan merupakan penyakit kronis yang masih menjadi masalah kesehatan di dunia termasuk Indonesia. World Health Organization (WHO) menyatakan bahwa TB saat ini telah menjadi ancaman global. Pada tahun
2012, diperkirakan 8,6 juta orang menderita TB dan 1,3 juta meninggal akibat penyakit ini. ${ }^{8}$

Cara yang paling efisien untuk mengendalikan TB adalah dengan penggunaan vaksin yang efektif. Vaksin yang saat ini digunakan untuk TB adalah Mycobacterium bovis Bacille Calmette-Guerin (BCG), tetapi di sebagian daerah, vaksin ini gagal memberikan perlindungan. Beberapa studi menunjukkan alasan utama keberhasilan yang rendah dari vaksin BCG disebabkan karena adanya gangguan imunitas oleh penyakit infeksi kronis yang ditandai dengan tingginya prevalensi penyakit infeksi kronis yang endemis, terutama yang disebabkan oleh cacing. ${ }^{9,10}$

Elias et al pada tahun 2001, menunjukkan bahwa respon sel $\mathrm{T}$ terhadap antigen mikobakteri tuberkulosis khususnya respon sel Th1 baik sebelum dan sesudah vaksinasi BCG rendah pada subyek yang terinfeksi cacing dibandingkan dengan subyek yang tidak terinfeksi cacing. ${ }^{9}$ Pada tahun 2012 , Vaca et al menyimpulkan bahwa booster BCG secara oral tidak meningkatkan secara signifikan kadar Interferon gamma (IFN-y) pada kelompok terinfeksi Ascaris lumbricoides yang tidak diberi obat, tetapi pada kelompok yang diobati dengan albendazole memiliki efek signifikan terhadap respon IFN-y. ${ }^{11}$ Data ini didukung oleh publikasi dari Gebreegziabiher et al (2014) yang menunjukkan adanya hubungan ibu yang terinfeksi cacing dengan peningkatan $\lg E$ total, IgG spesifik dan penurunan IFN-y pada darah tali pusat. ${ }^{12}$ Tahun 2012 Mehta et al membuktikan bahwa bayi yang lahir dari ibu yang terinfeksi STH memiliki kadar IL-10 yang lebih tinggi dibandingkan dengan bayi yang lahir dari ibu yang tidak terinfeksi STH. Hal ini penting karena vaksinasi BCG saat ini sebagian besar diberikan secara langsung setelah kelahiran. ${ }^{13}$

Terlihat ada tumpang tindih antara rendahnya tingkat keberhasilan vaksin BCG dan tingginya infeksi cacing. Studi yang meneliti hubungan antara indikator infeksi cacing dan penyakit TB menunjukkan bahwa infeksi cacing dapat mengganggu imunitas terhadap mikobakteri. Perlindungan terhadap mikobakteri membutuhkan respon imun adaptive seluler yang efektif yang ditandai dengan imunitas sel Th1 yang tinggi dengan produksi sitokinnya seperti IFN- $\mathrm{y}$, tumor 
necrosis factor alpha (TNF- $\alpha$ ), dan Interleukin-12 (IL12), sedangkan infeksi cacing kronis tidak hanya dapat mengakibatkan proliferasi dan diferensiasi sel Tho menjadi Th1 dan Th2 saja, tetapi juga dapat menginduksi perkembangan sel $T$ reg yang memproduksi IL-10 dan TGF- $\beta$ yang akan mempengaruhi penurunan respon sel Th1 dan Th2 dengan demikian infeksi cacing kronis ini akan menekan respon sel Th1 yang sangat penting untuk respon imun tubuh terhadap infeksi mikobakteri dan akhirnya dapat mengurangi efektifitas vaksinasi. 7,14,15

Berdasarkan cellular hyporesponsive yang diakibatkan oleh infeksi cacing kronis, maka perlu diteliti perbedaan kadar IFN- $y$ dan IL-10 pada orang dewasa terinfeksi Ascaris lumbricoides dengan tidak terinfeksi yang diinduksi vaksin BCG, sehingga akan dapat diketahui apakah terdapat perbedaan respon imun terhadap antigen vaksin BCG pada individu yang terinfeksi Ascaris lumbricoides dengan individu yang tidak terinfeksi Ascaris lumbricoides.

\section{METODE}

Jenis penelitian ini adalah penelitian observasional dengan menggunakan rancangan cross sectional study. Populasi penelitian adalah orang dewasa Kelurahan Muara Fajar Kecamatan Rumbai Pesisir Pekanbaru yang terinfeksi dan tidak terinfeksi Ascaris lumbricoides. Besar sampel dalam penelitian adalah 14 orang dewasa perkelompok. Untuk pemeriksaan feses dilakukan di Laboratorium Parasitologi Akademi Analis Kesehatan Fajar Pekanbaru dan pemeriksaan sampel darah dilakukan di Laboratorium Biomedik Fakultas Kedokteran Universitas Andalas. Variabel independen adalah orang dewasa terinfeksi dan tidak terinfeksi Ascaris lumbricoides dan variabel dependen adalah IFN-y dan IL-10.

Prosedur Kerja : Dilakukan pemeriksaan feses pada orang dewasa untuk mendeteksi infeksi cacing, kemudian dilakukan pengambilan sampel darah 2,5 $\mathrm{mL}$ pada masing-masing kelompok, isolasi limfosit, penghitungan jumlah limfosit dan pengenceran, selanjutnya kultur sel limfosit, panen produk kultur dan pemeriksaan kadar IFN-y dan IL-10. Analisis Data: Analisis data yang digunakan adalah uji t.
HASIL

Variabel yang diperiksa pada penelitian ini adalah kadar IFN-y dan IL-10. Hasil pengukuran kadar IFN-y dan IL-10 dapat dilihat pada Tabel 1 dan 2 berikut ini.

Tabel 1. Perbedaan kadar rerata IFN- $\gamma$ pada orang dewasa yang terinfeksi Ascaris lumbricoides dengan tidak terinfeksi yang diinduksi vaksin BCG

\begin{tabular}{lcc}
\hline $\begin{array}{c}\text { Status Infeksi } \\
\text { Ascaris lumbricoides }\end{array}$ & $\begin{array}{c}\text { IFN- } \mathbf{p}(\mathbf{p g} / \mathbf{m l}) \\
\text { Mean } \pm \text { SD }\end{array}$ & p \\
\hline Terinfeksi Ascaris & $16,55 \pm 14,13$ & \\
lumbricoides (+) & & 0,000 \\
Tidak terinfeksi Ascaris & & \\
lumbricoides (-) & $199,36 \pm 121,86$ & \\
\hline
\end{tabular}

Tabel 2. Perbedan kadar rerata IL-10 pada orang dewasa yang terinfeksi Ascaris lumbricoides dengan tidak terinfeksi yang diinduksi vaksin BCG

\begin{tabular}{lcc}
\hline $\begin{array}{c}\text { Status Infeksi } \\
\text { Ascaris lumbricoides }\end{array}$ & $\begin{array}{c}\text { IL-10 }(\mathbf{p g} / \mathbf{m l}) \\
\text { Mean } \pm \text { SD }\end{array}$ & p \\
\hline Terinfeksi Ascaris & $36,13 \pm 8,83$ & \\
lumbricoides (+) & & 0,000 \\
Tidak terinfeksi Ascaris & & \\
lumbricoides (-) & $10,57 \pm 9,20$ & \\
\hline
\end{tabular}

\section{PEMBAHASAN}

Berdasarkan Tabel 1, didapatkan bahwa rerata kadar IFN-y pada orang dewasa yang terinfeksi Ascaris lumbricoides yaitu 16,55 $\pm 14,13 \mathrm{pg} / \mathrm{ml}$, sedangkan rata-rata kadar IFN-y pada orang dewasa yang tidak terinfeksi Ascaris lumbricoides yaitu 199,36 $\pm 121,86 \mathrm{pg} / \mathrm{ml}$, dengan $\mathrm{p}<0,005(0,00)$, artinya terdapat perbedaan bermakna kadar IFN-y pada orang dewasa yang terinfeksi Ascaris lumbricoides dengan orang dewasa yang tidak terinfeksi Ascaris lumbricoides.

Kelompok perlakuan yang terinfeksi Ascaris lumbricoides mempunyai kadar IFN- $y$ yang lebih rendah dibandingkan dengan kelompok kontrol yang tidak terinfeksi Ascaris lumbricoides. Hal ini disebabkan karena selama infeksi cacing kronis, sebenarnya sistem imun hospes mengenali antigen asing lain tetapi terhambat oleh aktivasi supresi atau mekanisme regulator. T reg yang dihasilkan selama infeksi cacing kronis akan mengekspresikan dan 
melepaskan IL-10 yang diduga petanda supresif, yang akan mempengaruhi penurunan respon sel Th1 dan Sel Th2, dengan demikian infeksi cacing kronis ini akan menekan respon sel Th1 untuk menghasilkan IFN-y. ${ }^{7,15-17}$

Hasil penelitian ini sama dengan penelitian yang dilakukan oleh Gebreegziabiher et al melakukan penelitian untuk mengetahui pengaruh ibu yang terinfeksi cacing usus terhadap fungsi imunitas tubuh ibu dan bayi dalam menanggapi tuberkulosis. Gebreegziabiher et al menyimpulkan bahwa kadar IFN-y secara signifikan lebih rendah pada subyek yang terinfeksi cacing usus dibandingkan dengan subyek yang tidak terinfeksi cacing usus. Hal ini disebabkan karena peningkatan aktivitas sel $\mathrm{T}$ reg yang bertanggung jawab untuk antigen tertentu yang diamati selama infeksi cacing kronis. ${ }^{12}$

Vaca et al pada tahun 2012 melakukan penelitian terhadap efek dari infeksi Ascaris lumbricoides pada respon imun terhadap booster BCG secara oral. Data yang diperoleh dari penelitian ini adalah bahwa booster BCG oral tidak meningkatkan secara signifikan kadar IFN-y sesudah vaksinasi pada anak terinfeksi Ascaris lumbricoides yang tidak diberi obat (albendazole), kegagalan ini memberikan bukti bahwa ada penghalang imunologis mukosa pada vaksinasi secara oral dan salah satu strategi yang dapat dilakukan untuk keberhasilan imunisasi ini adalah dengan meningkatan kesehatan mukosa, diantaranya dengan memberikan pengobatan obat cacing sebelum vaksinasi. ${ }^{11}$

Pada tahun 2001 Elias et al juga melakukan penelitian yang bertujuan untuk melihat pengaruh respon sel $T$ pada manusia terhadap antigen mikobakteri pada individu yang terinfeksi cacing sebelum dan sesudah vaksinasi BCG. Hasil penelitian yang diperoleh adalah kelompok yang diobati dengan albendazole setelah vaksinasi menghasilkan jumlah IFN- $y$ yang signifikan lebih tinggi dibandingkan dengan prevaksinasi $(p=0,03)$ sedangkan, pada kelompok plasebo perbedaannya tidak signifikan. Elias et al menyimpulkan bahwa respon sel $\mathrm{T}$ terhadap antigen mikobakteri tuberkulosis khususnya respon sel Th1 baik sebelum dan sesudah vaksinasi BCG rendah pada subyek yang terinfeksi cacing. ${ }^{9}$
Pada tahun 2008 Elias et al kembali melakukan penelitian dengan merekrut relawan yang tidak terinfeksi mikobakteri sebelumnya dan yang terinfeksi cacing usus. Hasil penelitian menunjukkan bahwa Peripheral Blood Mononuclear Celss (PBMCs) yang diperoleh dari kelompok plasebo memiliki frekuensi IFN-y yang lebih rendah dibandingkan dengan kelompok yang diberi obat anti cacing (129 vs $191, p=$ 0,03 ) ketika distimulasi secara invitro dengan antigen mikobakteri. Ini menunjukkan bahwa infeksi cacing mengganggu imunogenisitas vaksinasi BCG yang diukur dengan produksi sitokin yang merespon antigen spesifik TB yaitu IFN- $y$, ini mendukung pandangan bahwa terapi anti cacing dari populasi yang terinfeksi cacing diperlukan untuk meningkatkan efektivitas BCG di negara-negara endemik cacing di daerah tropis. ${ }^{18}$

Elias et al menyimpulkan bahwa pengobatan infeksi cacing selama vaksinasi BCG dapat meningkatkan secara signifikan proliferasi dan respon IFN-y terhadap mikobakteri tuberkulosis, implikasinya adalah bahwa paparan cacing usus selama vaksinasi BCG dapat berkontribusi pada penurunan respon sel T terhadap antigen mikobakteri. ${ }^{18}$

Implikasi dari hal ini adalah bahwa individu yang terinfeksi cacing kronis mungkin memiliki peningkatan kerentanan terhadap infeksi yang biasanya direspon oleh imunitas sel Th1 dan infeksi cacing ini juga dapat mengubah respon imun untuk vaksin yang berpotensi diarahkan terhadap infeksi intraseluler menjadi menurun. ${ }^{19}$

Berdasarkan Tabel 2 didapatkan bahwa rerata kadar IL-10 pada orang dewasa yang terinfeksi Ascaris lumbricoides yaitu $36,13 \pm 8,83 \mathrm{pg} / \mathrm{ml}$, sedangkan pada orang dewasa yang tidak terinfeksi Ascaris lumbricoides yaitu $10,57 \pm 9,20 \mathrm{pg} / \mathrm{ml}$, dengan $\mathrm{p}<0,05(0,00)$, artinya terdapat perbedaan bermakna kadar IL-10 antara orang dewasa yang terinfeksi Ascaris lumbricoides dengan orang dewasa yang tidak terinfeksi Ascaris lumbricoides. Hal ini menunjukkan kelompok perlakuan yang terinfeksi Ascaris lumbricoides mempunyai kadar IL-10 yang lebih tinggi dibandingkan dengan kelompok kontrol yang tidak terinfeksi Ascaris lumbricoides.

Hasil penelitian sebelumnya menunjukkan bahwa infeksi cacing berhubungan dengan sel $\mathrm{T}$ reg 
yang ditandai dengan peningkatan ekspresi IL-10.20,21 $\mathrm{T}$ reg awalnya dianggap untuk mengatur toleransi terhadap antigen diri, tetapi populasi sel T yang sama kini telah terbukti terlibat dalam respon terhadap antigen eksogen termasuk bakteri. Studi lain juga menunjukkan bahwa $\mathrm{T}$ reg yang dihasilkan selama infeksi cacing dapat mempengaruhi respon imun terhadap vaksinasi. ${ }^{18}$

Pada tahun 2010, Figueiredo et al melakukan penelitian untuk melihat efek dari infeksi kronis cacing usus terhadap produksi sitokin Th1, Th2, $\mathrm{T}$ reg dan produksi antibodi IgE dan IgG4 pada anak yang tinggal di daerah miskin kota. Hasil penelitian yang diperoleh adalah produksi IL-10 lebih tinggi pada anak yang terinfeksi dengan cacing usus daripada anak yang tidak terinfeksi $(\mathrm{P}<0,001)$. Figueiredo $d k k$ menyimpulkan bahwa infeksi cacing usus menghasilkan efek homeostatis melalui produksi IL-10 dengan menekan produksi sitokin lainnya terutama selama infeksi kronis. ${ }^{22}$

Penelitian yang dilakukan oleh Mehta et al pada 2012 terhadap kadar IL-10 pada anak usia 13-18 bulan dengan ibu yang terinfeksi STH sebelumnya dibandingkan dengan ibu yang tidak terinfeksi selama kehamilan. Bayi yang baru lahir dari ibu yang terinfeksi memiliki kadar IL-10 yang lebih tinggi dibandingkan dengan ibu yang tidak terinfeksi $(P=0,033)$. Mehta et al menyimpulkan bahwa peningkatan produksi IL-10 adalah gambaran dari infeksi cacing kronis. Peningkatan ini memiliki efek penting dalam modulasi respon inflamasi yang dapat meningkatkan kerentanan terhadap infeksi lainnya seperti dapat mengubah respon imun untuk TB. ${ }^{13}$

Resende et al pada tahun 2006 juga melakukan penelitian untuk melihat dampak infeksi cacing usus pada respon anti TB pada pasien TB dan pasien TB bersamaan dengan infeksi cacing usus (TB + cacing), hasil penelitian ini menunjukkan bahwa infeksi cacing usus pada pasien TB memiliki dampak negatif, pada awal pengobatan, frekuensi IFN-ץ secara signifikan lebih rendah pada pasien TB+cacing dan pada akhir pengobatan IFN-y juga tetap lebih rendah pada pasien TB+cacing dibandingkan pasien TB. Menariknya, frekuensi IL-10 tidak berbeda secara signifikan pada pasien TB dan TB+cacing pada awal pengobatan, namun pada akhir pengobatan IL-10 menurun secara signifikan pada pasien TB tetapi tetap tinggi pada pasien TB+cacing. ${ }^{23}$

Resende et al menyimpulkan pada akhir pengobatan TB, produksi IFN-Y yang rendah mungkin akibat dari produksi IL-10 yang tinggi. Infeksi cacing usus dapat menginduksi produksi IL-10 yang tinggi dan juga berperan pada supresi imun terhadap TB aktif. Pasien TB dengan infeksi cacing yang bersamaan menunjukkan perubahan distribusi subset sel $\mathrm{T}$ dan peningkatan $\mathrm{IL}-10$ dibandingkan dengan pasien TB yang tidak terinfeksi cacing. Diagnosis dan pengobatan cacing usus mungkin penting untuk respon yang sukses terhadap pengobatan TB, ini sangat penting untuk keberhasilan dari upaya global untuk mengendalikan TB. ${ }^{23}$

Infeksi cacing selain merangsang respon sel Th2 yang kuat, juga menginduksi populasi sel $\mathrm{T}$ supressive yang dikenal sebagai sel T reg. ${ }^{24}$ Mahanty et al, 1997 dan King et al, 1993 menunjukkan bahwa terdapat sel-sel spesifik antigen cacing yang tinggi dan respon sel Th1 yang rendah pada orang yang terinfeksi cacing dan reaktivitas mereka dapat kembali dengan adanya antibodi yang menetralisir sitokin regulator IL-10 dan TGF- $\beta$. Hal ini diaporkan dan menjadi bukti peningkatan aktivitas sel $\mathrm{T}$ reg selama infeksi cacing kronis. ${ }^{25,26}$

Sel T reg menghasilkan sitokin inhibitor (IL-10, TGF- $\beta$ ) yang dapat menekan respon inflamasi. Perubahan dalam respon imun yang disebabkan oleh infeksi cacing kronis dapat berdampak pada kemampuan host untuk mengatasi infeksi yang tidak terkait lainnya seperti TB. Bukti lain dampak cacingan pada respon terhadap mikobakteri juga dilakukan oleh Elias et al 2001 di Ethiopia yang membuktikan bahwa individu yang terinfeksi cacing memiliki respon seluler terhadap antigen spesifik TB yang rendah dan produksi sitokin inhibitor yang lebih tinggi jika dibandingkan dengan individu yang tidak terinfeksi cacing. ${ }^{9}$

\section{KESIMPULAN}

Terdapat perbedaan kadar IFN-y pada orang dewasa terinfeksi Ascaris lumbricoides dengan tidak terinfeksi yang diinduksi vaksin BCG. 
Terdapat perbedaan kadar IL-10 pada orang dewasa terinfeksi Ascaris lumbricoides dengan tidak terinfeksi yang diinduksi vaksin BCG.

\section{UCAPAN TERIMA KASIH}

Terimakasih kepada Kepala Laboratorium Biomedik Fakultas Kedokteran Universitas Andalas Padang dan Kepala Laboratorium Akademi Analis Kesehatan Fajar Pekanbaru sehingga dapat menyelesaikan penelitian ini.

\section{DAFTAR PUSTAKA}

1. World Health Organization. Soil transmitted helminthiases. 2012.

2. Departemen Kesehatan RI. Profil kesehatan Indonesia 2009. Jakarta: Pusat Data dan Informasi; 2011.

3. Ikhsan A. Hubungan prilaku higiene dan status gizi dengan infestasi soil transmitted helminth pada murid SDN 008 Sukaping Kecamatan Pangean Kabupaten Kuantan Sengingi. Pekanbaru: Fakultas Kedokteran Universitas Riau; 2012.

4. Elias D, Akuffo $\mathrm{H}$, Britton s. Helmint could influence the outcome of vaccines against TB in the tropics. Parasite Immunology. 2006;28:507-13.

5. Smits HH, Everts B, Hartgers CF, Yazdanbakhsh. Chronic helminth infection protect against allergic diseases by active regulatory processes. Curr Allergy Asthma Rep. 2010;10:3-12.

6. Mendez P, Samperio. Immunological mechanisme by which concomitant helminth infections predispose to the development of human tuberculosis. Korean J Parasitol. 2012;4:281-6.

7. Nel Hendrik J, Nelita du P, Leanie K, Loxton AG, Helden PDV, Gerhard W. Mycobacterium bovis BCG infection severely delays Trichuris muris expulsion and co-infection suppresses immune responsiveness to both pathogens. BMC Microbiology. 2014;14(9):1471-2180

8. World Health Organization. Global tuberculosis report. 2013.

9. Elias D, Wolda D, Akuffo H, Petros B, Broner U, Britoton S. Effect of deworming on human $\mathrm{T}$ cell responses to mycobacterial antigens in helmintexposed individuals before and after Bacille
Calmette-Guerin (BCG) vaccination. Clin Exp Immunol. 2001;123:219-25.

10. Meseret W, Biniam M, ZinayeT. Effect of helminths on immunity, clinical respon and vaccination againts tuberculosis. Advanced Journal of Biological Research. 2013; (002):013-021.

11. Vaca M, Moncayo A L, Cosgrove AC, Chico EM, Branco LR, Castello LDJ, et al. A single dose of oral BCG Moreaou fails to tuberculin in children in the rural tropics: evidence for a barrier to mucosal immunization. Journal of Tropical Medicine. 2012; 10(1555).

12. Gebreegziabiher D, Desta K, Desalegn G, Howe R, Abebe M. The effect of maternal helmint infection on maternal and neonatal immune function and immune to tuberculosis. Plos One. 2014;9(4): e93429.

13. Mehta Raaj S, Rodriguez A, Chico, Martha, Guadalupe I, Brancano N, Sandoval C, et al. Maternal geohelminth infections are associated with an increased susceptibility to geohelminth infection in children: a case-control study. Plos Neglected Tropical Diseases. 2012;6(7):e1753.

14. Maizels RM, Yazdanbakhsh. Immune regulation by helminth parasites. celuler and molecular mechanism. Nature Review Imunologi. 2003;3: 733-44.

15. Soelen Nelda van, Mandalakas Anna M, Kirchner HL, Walzl G, Grewal HMS, Jacobsen M, et al. Effect Of Ascaris lumbticoides specific $\lg E$ on Tuberculin skin test responses in children in a highburden-setting: a cross-sectional community-based study: BMC Infectious diseases. 2012;12(211): 1471-2334.

16. Maizels RM, Balic A, Escobar NG, Nair M, Taylor MD, Allen J. Helminth parasites-master of regulation. Immunological Reviews. 2004;20:89116.

17. Darwin E. Imunologi dan infeksi. Padang: Andalas University Press. 2000.

18. Elias D, Britton S, Aseffa A, Engers $H$, Akuffo $H$. Poor immunogenicity of BCG in helminth infected population is associated with increased in vitro TGF- $\beta$ production. Vaccine. 2008;26:3897-902.

19. Raviglione MC, Snider DE Jr, Kochi A. Global 
epidemiology of tuberculosis. morbidity and mortality of a worldwide epidemic. JAMA. 1995;273:220-6.

20. Leng Q, Bentwich Z, Borkow G. Increased TGFbeta, Cbl-b and CTLA-4 levels and Immunosuppression in association with chronic immune activation. Int Immunol. 2006;18:637-44.

21. Babu S, Blauvelt CP, Kumaraswami V, Nutman TB. Regulatory networks induced by live parasites impair both Th1 and Th2 Pathways in patent Lymphatic Filari-Asis: Implications for parasite persistence. J Immunol. 2006;176:3248-56.

22. Figueiredo CA, Barreto ML, Rodrigues LC, Cooper PJ, Silva NB, Amorim LD, et al. Chronic intestinal helminth infections are associated with immune hyporesponsiveness and induction of a regulatory network. Infection and Immunity. 2010;78(7): 3160-7.
23. Resende CT, Hirsch CS, Toossi Z, Dietze R, Ribeiro-Rodrigues $R$. Intestinal helminth coinfection has a negative impact on both antiMycobacterium Tuberculosis immunity and clinical response to tuberculosis therapy. Clin Exp Immunol. 2006;147:45-52.

24. Belkaid Y, Rouse BT. Natural regulatory T cells in infectious disease. Nat Immunol. 2005;6:353-60.

25. Mahanty S, Mollis SN, Ravichandran M, Abrams JS, Kumaraswami V, Jayaraman K. High levels of spontaneous and parasite antigen-driven interleukin-10 production are associated with antigen-specific hyporesponsiveness in human lymphatic filariasis. J Infect Dis. 1996;173:769-73.

26. King CL, Mahanty S, Kumaraswami V. Cytokine control of parasite-specific anergy in human lymphatic filariasis. Preferential induction of a regulatory $t$ helper type 2 lympho-cyte subset. J Clin Invest. 1993;92:1667-73. 